\title{
Provizórikus veserákaltípusok a 2016. évi WHO-klasszifikációt követően
}

\author{
Jenei Alex dr. ${ }^{1}$ - Hes Ondrej dr. ${ }^{2}$ - Kuthi Levente $\mathbf{d r} .^{1}$ \\ ${ }^{1}$ Szegedi Tudományegyetem, Általános Orvostudományi Kar, Patológiai Intézet, Szeged
}

${ }^{2}$ Charles University Hospital, Plzeň

\begin{abstract}
A vesesejtes carcinoma (RCC) többféle, a veséből kiinduló rosszindulatú daganattípus gyưjtőneve. Az egyes entitások sajátos epidemiológiai, morfológiai, immunhisztokémiai, genetikai és klinikai jellemvonásokkal bírnak. Ezek együttes figyelembevételével került publikálásra 2016-ban a vesedaganatok aktuális WHO-klasszifikációja. Az eltelt három év során újabb, provizórikus RCC-altípusok kerültek leírásra, melyek egyelőre nem képezik részét a hivatalos beosztásnak. Ebben az összefoglalóban ezek az entitások kerülnek részletes áttekintésre. A szerzők bemutatják a következő daganattípusok klinikopatológiai jellegzetességeit: pajzsmirigyszerü follicularis carcinoma, az $A L K$-transzlokációhoz társult carcinoma, vesesejtes carcinoma prominens simaizomstromával, fumarát-hidratáz-deficiens carcinoma, bifázisos squamoid papillaris carcinoma, eosinophil solid és cysticus carcinoma, atrophiás vesére emlékeztető carcinoma, világossejtes carcinoma óriássejtekkel és emperipolesissel, Warthin-szerü papillaris carcinoma, low-grade oncocytás vesetumor (CD117-negatív, CK7-pozitív), high-grade oncocytás vesetumor, TCEB1-mutáns carcinoma és neuroendokrin vonásokkal rendelkező chromophob carcinoma. Ha a patológus követi az aktuális leletezési protokollokat, akkor ezek az entitások jórészt nem osztályozható RCC-ként kerülnek diagnosztizálásra. A munka meg kívánja ismertetni ezeket az altípusokat a hazai patológus-, onkológus- és urológusközösséggel azért, hogy javuljon a diagnosztikus pontosság, valamint hogy elkezdődhessen az ilyen esetek gyưjtése és további célzott vizsgálata is.

Orv Hetil. 2020; 161(3): 83-94.
\end{abstract}

Kulcsszavak: RCC, vesesejtes carcinoma, klasszifikáció, WHO

\section{Provisional renal cell carcinoma subsets following the 2016 WHO classification}

Renal cell carcinoma (RCC) represents a heterogenous group of malignant tumors that originate from the kidney parenchyma. The different entities have their own specific epidemiological, morphological, immunohistochemical, genetic and clinical characteristics. The new WHO classification of renal tumors was published in 2016, and it takes all of these features together into account. Although in the past three years, several emerging subtypes have been described, these are not yet included in the current classification. In this review paper, these entities are summarized in details including the following emerging subsets: thyroid-like follicular carcinoma, $A L K$ rearrangement-associated RCC, renal cell carcinoma with prominent smooth muscle stroma, fumarate hydratase-deficient RCC, biphasic squamoid papillary RCC, eosinophilic solid and cystic RCC, atrophic kidney-like RCC, clear cell RCC with giant cells and emperipolesis, Warthin-like papillary RCC, low-grade oncocytic renal tumor (CD117-negative; CK7-positive), highgrade oncocytic renal tumor, TCEBI-mutated RCC and chromophobe RCC with neuroendocrine features. These entities are mostly diagnosed as RCC unclassified. The aim of this study is to introduce these subsets to the Hungarian pathologists, oncologists and urologists, to prompt diagnostic accuracy and to facilitate a collection along with a consecutive analysis of these cases.

Keywords: RCC, renal cell carcinoma, classification, WHO

Jenei A, Hes O, Kuthi L. [Provisional renal cell carcinoma subsets following the 2016 WHO classification]. Orv Hetil. 2020; 161(3): 83-94.

(Beérkezett: 2019. október 4.; elfogadva: 2019. november 6.) 


\section{Rövidítések}

$2 \mathrm{SC}=(\mathrm{S}$-[2-succino $]$ cysteine $) \mathrm{S}$-(2-szukcinil $)$-cisztein; ALK = anaplasticus lymphoma kináz; AMACR = (alpha-methylacylcoenzyme A racemase) alfa-metil-acil-koenzim-A-racemáz; BerEP4 = epithelialis sejtadhéziós molekula; CA9 $=($ carbonic anhydrase 9) szénsavanhidráz-9; CCPRCC = (clear cell papillary renal cell carcinoma) világossejtes papillaris vesesejtes carcinoma; $\mathrm{CD}=$ (cluster of differentiation) differenciációs klaszter; $\mathrm{ChRCC}=($ chromophobe renal cell carcinoma $)$ chromophob vesesejtes carcinoma; $\mathrm{CK}=$ citokeratin $; \mathrm{CMV}=$ cytomegalovírus; EMA = epithelialis membránantigén; ESC RCC = (eosinophilic solid and cystic renal cell carcinoma) eosinophil solid és cysticus vesesejtes carcinoma; $\mathrm{FH}$ = fumarát-hidratáz; FISH $=$ (fluorescence in situ hybridization) fluoreszcens in situ hibridizáció; HIFl $\alpha$ = hypoxia indukálta faktor- 1 -alfa; HLRCC $=$ (hereditary leiomyomatosis and renal cell carcinoma) öröklo" dő leiomyomatosis és vesesejtes carcinoma; HMB45 = human melanoma black 45 ; INIl = integráz interaktor- 1 ; ISUP $=($ International Society of Urologic Pathology) Nemzetközi Uropatológiai Társaság; $\mathrm{MA}=$ metanephricus adenoma; MelanA = melanoma antigen recognized by $\mathrm{T}$ cells $\mathrm{l}$; MIA $=$ antimitokondriális antitest; MiTF $=$ microphthalmia-asszociált transzkripciós faktor; $\mathrm{mTOR}=($ mammalian target of rapamycin $)$ a rapamicin célpontja emlősökben; MTSC RCC = (mucinous tubular and spindle cell carcinoma) mucinozus, tubuláris és orsósejtes vesesejtes carcinoma; NGS = (next generation sequencing) új generációs szekvenálás; p63 = tumorprotein-63; PAX = paired box protein; $\mathrm{RCC}=$ (renal cell carcinoma) vesesejtes carcinoma; $\mathrm{SDHB}=$ (succinate dehydrogenase subunit $\mathrm{B})$ a szukcinát-dehidrogenáz B-alegysége; TCEBl = (transcription elongation factor B subunit 1) transzkripciós elongációs faktor $\mathrm{B} 1 ; \mathrm{TF}=$ transzkripciós faktor; $\mathrm{TMP} 3=$ tropomiozin- 3 ; TTFl $=($ thyroid transcription factor 1$)$ pajzsmirigy-transzkripciós faktor-1; VCL = vinkulin; VHL = von Hippel-Lindau; $\mathrm{WHO}=$ (World Health Organization) Egészségügyi Világszervezet

A vesesejtes carcinoma (Renal cell carcinoma, RCC) klasszifikációja jelentős változáson ment keresztül az eltelt 20 év során. Az 1997-ben publikált Heidelbergklasszifikáció tekinthető a veserákok első modern csoportosításának, ugyanis ez a rendszer már hangsúlyosan figyelembe vette a daganatsejtekben észlelhető genetikai eltéréseket is [1]. Ezt a szemléletet tükrözte a 2004-ben kiadott WHO-klasszifikáció is, mely ismertette az egyes altípusok klinikai, fénymikroszkópos, immunhisztokémiai és genetikai jellemvonásait [2]. A következő években ugyan számos új entitás került leírásra, de az újabb egységes klasszifikáció megjelenésére 2013-ig kellett várni. Az International Society of Urological Pathology (ISUP) 2012-ben Vancouverben tartott konszenzuskonferenciáján ajánlásokat fogalmaztak meg a veserákok kategorizálását illetően, megalkottak egy új gradusrendszert, továbbá áttekintettek számos prognosztikai faktort és stádiumot befolyásoló tényezőt is, melyeket a szövettani leletnek tartalmaznia kell [3-5]. Az elkészített ún. Vancouver-klasszifikáció képezte az alapját a 2016-ban publikált és jelenleg is érvényben lévő WHO-osztályozásnak (1. táblázat) [6]. A fejlődés azonban nem állt le, ugyan-
1. táblázat $\mid$ A vesesejtes carcinoma WHO-klasszifikációja, illetve a provizó rikus entitások listája

Vesesejtes carcinoma altípus - a WHO 2016. évi klasszifikációjában szerepel

Világossejtes carcinoma

Multilocularis cysticus renalis neoplasia alacsony malignitási potenciállal

Papillaris carcinoma (WHO 1-es és 2-es típus)

Chromophob carcinoma

Gyújtőcsatorna-carcinoma

Medullaris carcinoma

MiTF-transzlokációhoz társult carcinoma (Xpl1.2 és t $[6 ; 11]$ carcinoma)

Mucinosus tubularis és orsósejtes carcinoma

Tubulocysticus carcinoma

Világossejtes papillaris carcinoma

Szukcinát-dehidrogenáz-deficiens carcinoma

Hereditaer leiomyomatosis és vesesejtes carcinoma szindrómához társult carcinoma

Szerzett cystás betegséghez társult carcinoma

Nem osztályozható carcinoma

Provizórikus altípus - a WHO 2016. évi klasszifikációjában nem szerepel

Pajzsmirigyszerü follicularis carcinoma

ALK-transzlokációhoz társult carcinoma

Vesesejtes carcinoma prominens simaizomstromával

Fumarát-hidratáz-deficiens carcinoma

Bifázisos squamoid papillaris carcinoma

Eosinophil solid és cysticus carcinoma

Atrophiás vesére emlékeztető carcinoma

Világossejtes carcinoma óriássejtekkel és emperipolesissel

Warthin-szerü papillaris carcinoma

Low-grade oncocytás vesetumor (CD117-negatív, CK7-pozitív)

High-grade oncocytás vesetumor

TCEB1-mutáns carcinoma

Chromophob carcinoma neuroendokrin vonásokkal

ALK = anaplasticus lymphoma kináz; CD117 = differenciációs klaszter-117; $\mathrm{CK} 7=$ citokeratin-7; $\mathrm{MiTF}=$ microphthalmia-asszociált transzkripciós faktor; TCEBl = transzkripciós elongációs faktor $\mathrm{Bl}$; $\mathrm{WHO}=$ Egészségügyi Világszervezet

is az elmúlt bő három évben további altípusok kerültek közlésre, melyeket a nemzetközi irodalom „emerging entities"-nek nevez [7]. Ezek leírása részben fénymikroszkópos és immunhisztokémiai jegyek, részben pedig a genetikai jellegzeteségek alapján történt. A mai modern onkológiai érában az újabb entitások ismerete elengedhetetlen, a célzott terápiás lehetőségek kiaknázása és végső soron a betegek jobb túlélése érdekében. Jelen dolgozatban a szerzők áttekintik a 2016 után leírt újabb, provizórikus veserákaltípusokat, hogy megismertessék azokat a hazai patológus-, onkológus- és urológusközösséggel. 


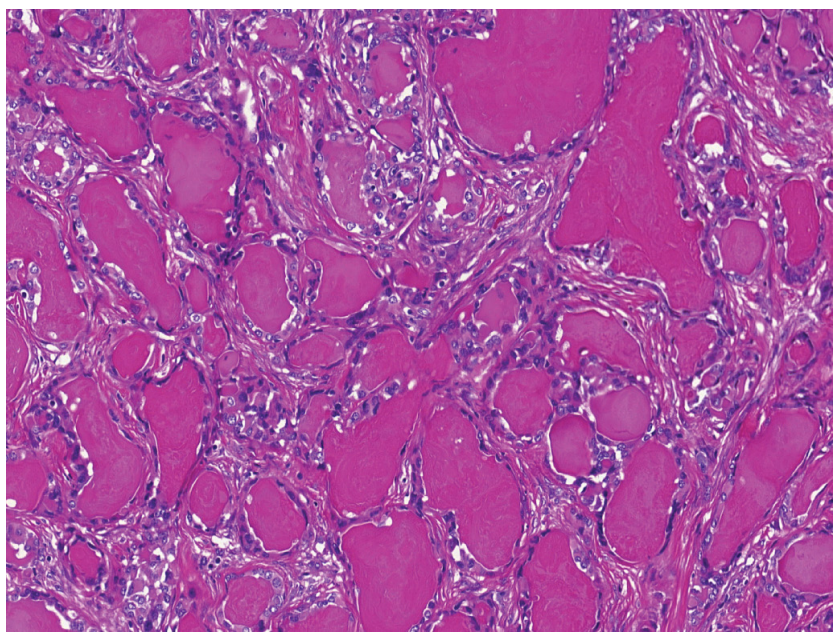

1. ábra

Pajzsmirigyszerű follicularis RCC. A szöveti kép a pajzsmirigy alapállományára emlékeztet. A daganatsejtek folliculusokat képeznek, melyekben besúrúsödött, kolloidszerű anyag található (hematoxilin-eozin festés, $20 \times$-os nagyítás)

$\mathrm{RCC}=$ vesesejtes carcinoma

\section{Pajzsmirigyszerü follicularis vesesejtes carcinoma (Thyroid-like follicular RCC)}

A pajzsmirigyszerü follicularis vesesejtes carcinoma esetismertetés formájában 2004-ben került leírásra, de csak 2009-ben láttak napvilágot olyan dolgozatok, melyek több esetet konzekvensen vizsgáltak $[8,9]$. Ez a tumortípus gyakrabban fordul elő nőkben, és a betegek életkora széles skálán váltakozik (19-83 év) [9]. Az eddig publikált esetek 44\%-át Kínában írták le [7]. A daganat általában indolens viselkedésú, de néhány esetben távoli disszeminációt is megfigyeltek [10]. A daganat makroszkóposan jellemzően jól körülírt, és áltokkal bír, továbbá mérete változó, és időnként igen nagyra nőhet
(11-118 mm) [9]. Szövetileg a daganat szerkezete emlékeztet a pajzsmirigy follicularis daganataira, ugyanis a tumorra a follicularis növekedési mintázat jellemző, a folliculusok centrumában pedig kolloidszerű anyag található (1. ábra). Az utóbbiakat bőséges citoplazmával rendelkező hengerhám vagy köbhám béleli. A daganat általában ISUP grade 2 -es vagy 3 -as differenciáltságú. Néhány daganatban kicsiny meszesedéseket is megfigyeltek $[7,9]$. A tumorsejtekben diffúzan pozitív a PAX2- és a PAX8-festés, valamint az esetek több mint 80\%-a CK7et is expresszál. Fontos kiemelni, hogy a daganat TTFlés tireoglobulin-negatív, ami segíti a daganat elkülönítését egy esetleges áttéti pajzsmirigy-eredetű follicularis vagy papillaris carcinomától [9]. Genetikailag a daganatot kromoszomális polysomiák és deletiók jellemzik, de egyelőre alacsony a genetikailag is vizsgált esetek száma [7].

\section{$A L K$-transzlokációhoz társult vesesejtes carcinoma ( $A L K$ rearrangement-associated RCC)}

Számos $A L K$-gén-eltéréshez kapcsolódó daganattípus ismert már (például tüdő-adenocarcinoma, inflammatoricus myofibroblastos tumor stb.) [11]. ALK-transzlokáció a veserákok kevesebb mint 1\%-ában fordul elö, ezért ennek a tumortípusnak a klinikopatológiai jellegzetességei még nincsenek teljesen felderítve [7]. Veserákokban a leggyakrabban a vinkulin (VCL), illetve a tropomiozin-3 (TPM3) a partnergének, melyek az ALK-fehérje aberráns expresszióját okozzák [7]. Egy újabb tanulmány szerint a gyermekkori, illetve fiatal felnőtt kori veserákok 3,8\%-a hordozza ezt a genetikai eltérést [12]. Enyhe férfipredominancia figyelhető meg, és az eddig leírt esetek széles életkori spektrumot mutatnak [7].
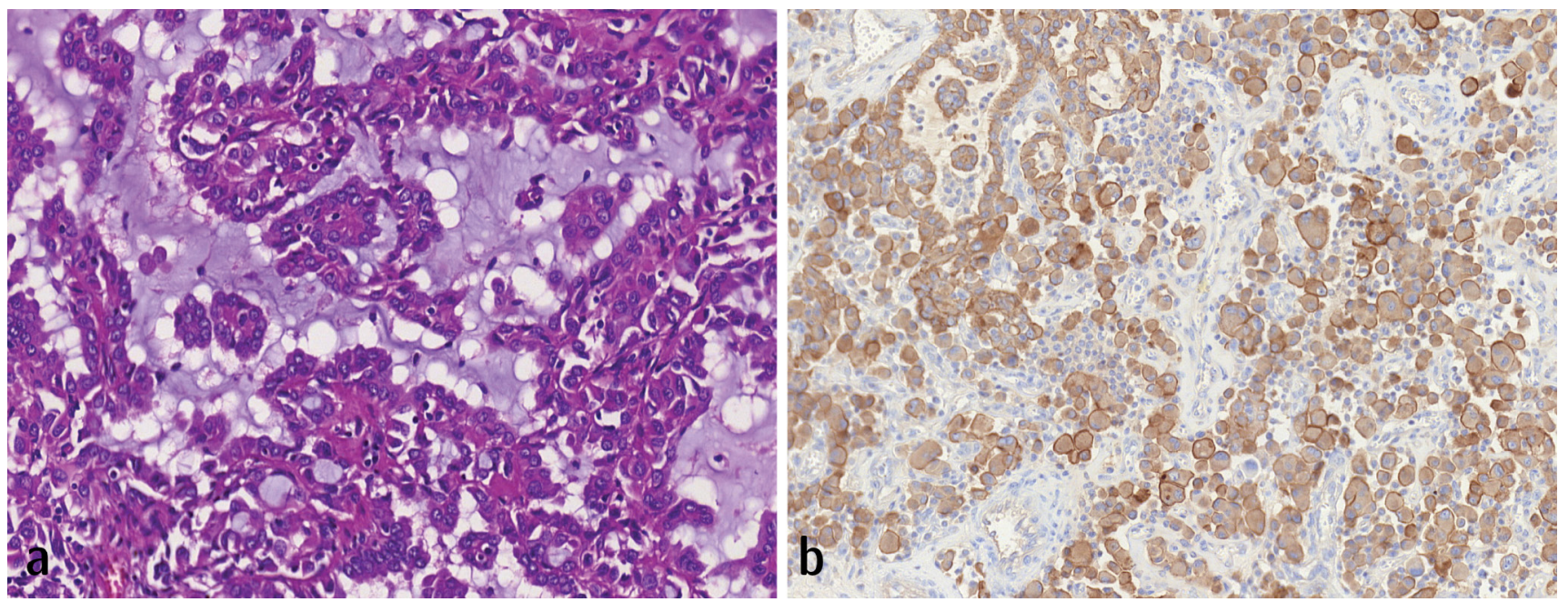

2. ábra

ALK-transzlokációhoz társult RCC. Ebben az esetben a partnergén a TPM3 volt. a) A növekedési mintázat papillaris, a citológiai atípia kifejezett, a stromában pedig mucin látható (hematoxilin-eozin festés, 20x-os nagyítás). b) A daganatsejtekben diffúz ALK-pozitivitás észlelhető (ALK-immunhisztokémia, 20×-os nagyítás)

ALK = anaplasticus lymphoma kináz; $\mathrm{RCC}$ = vesesejtes carcinoma; TPM3 = tropomiozin-3 

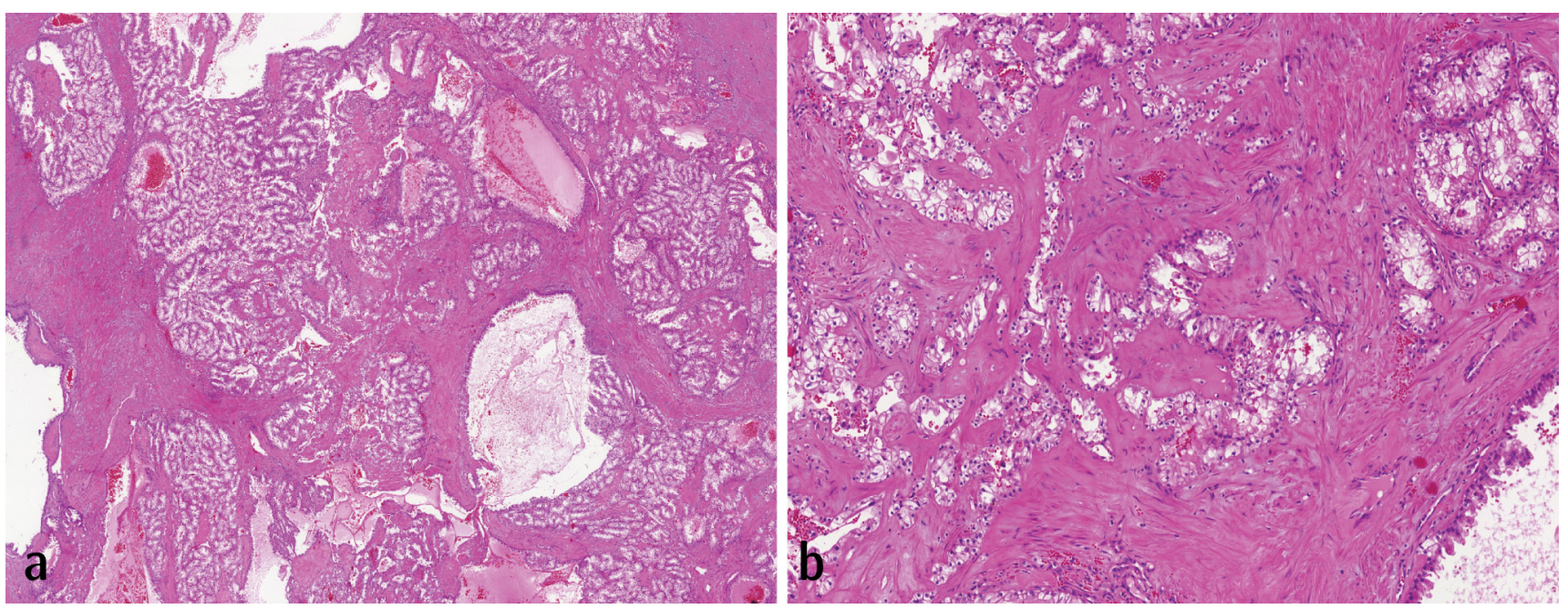

3. ábra

Vesesejtes carcinoma prominens simaizomstromával. a) A tumorsejtek solid fészkeket formálnak, melyeket simaizomban gazdag stroma vesz körül (hematoxilin-eozin festés, $5 \times$-ös nagyítás). b) A tumorsejtek világos citoplazmával rendelkeznek, a stromában vaskos simaizomkötegek látszanak (hematoxilin-eozin festés, $10 \times$-es nagyítás)

Szövetileg a $V C L-A L K$ és TPM3-ALK transzlokációt hordozó esetek diffúz reticularis vagy tubularis növekedésűek, továbbá prominens érhálózattal is rendelkeznek (2a ábra). A daganatsejtek alakilag igen változatosak, citoplazmájuk pedig eosinophil, melyben gyakran látni intracitoplazmatikus lumeneket is. Ezzel szemben a non$V C L /$ non-TPM3-ALK transzlokált esetek morfológiailag sokkal változatosabbak, gyakran papillaris, cribriform, solid, tubularis vagy tubulocysticus növekedést mutatnak. Ezekben az esetekben a stromában gyakran észlelni mucint is $[13,14]$. Immunhisztokémiailag a legfontosabb a diffúz citoplazmatikus és membranosus ALK-pozitivitás (2b ábra). Ugyanakkor a diagnózis csak genetikai vizsgálatok után állítható fel [7]. Ez történhet fluoreszcens in situ hibridizációval, illetve új generációs szekvenálással is. Az utóbbi előnye, hogy képes a partnergént is azonosítani. Differenciáldiagnosztikailag szóba jön a gyújtőcsatorna-carcinoma, a medullaris RCC, a MiTF-transzlokációhoz társult RCC, valamint a mucinosus tubularis és orsósejtes RCC [7]. Ezek közül részletesebben tárgyaljuk a medullaris és a MiTF-transzlokációhoz társult RCC-t. Az előbbi sarlósejtes vérszegénységhez társul, továbbá ez az egyetlen felnőttkori vesetumor, melyre az INIl-gén-vesztés jellegzetes. Az utóbbi pedig pozitív a melanocytamarkerekkel, tovább a transzlokáció típusát illetően vagy TFE3-, vagy pedig TFEB-gén-eltérés azonosítható benne. Az esetleges $A L K$-transzlokáció felderítésének nemcsak a diagnózis felállításában van szerepe, hanem rekurráló és disszeminálódott esetekben ígéretes terápiás célpont is.
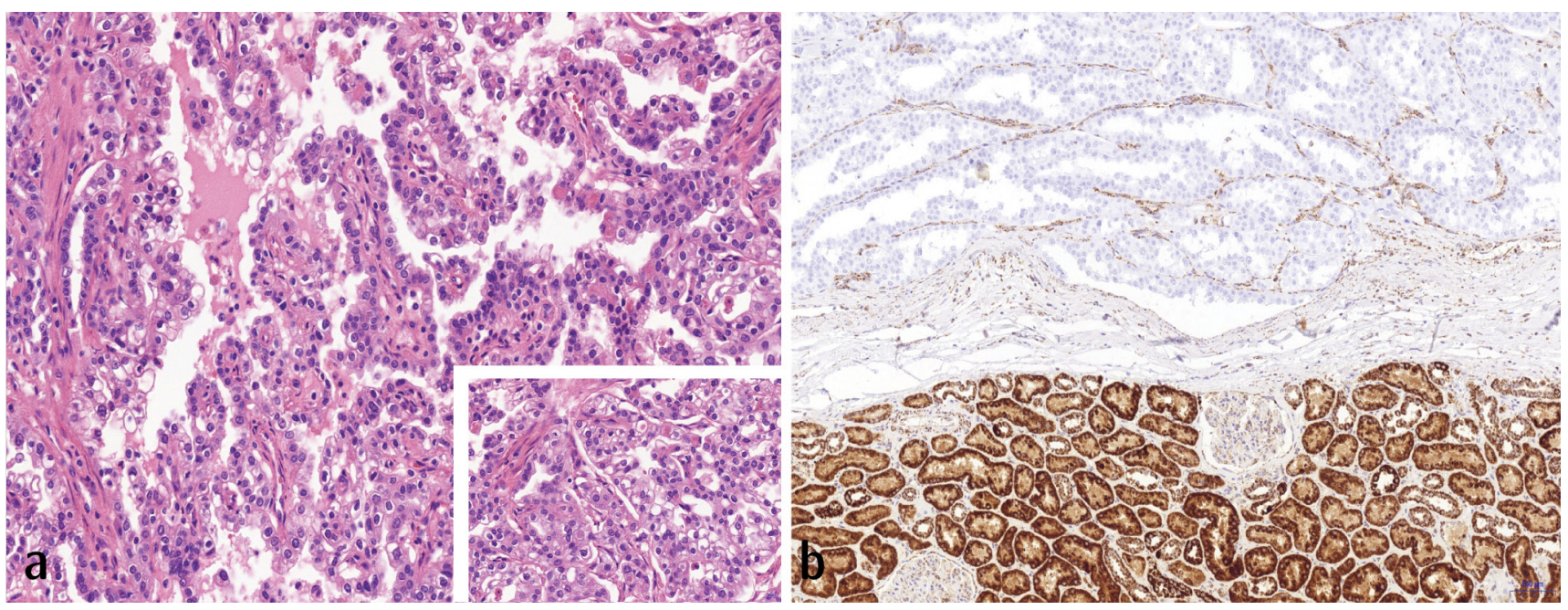

4. ábra

Fumarát-hidratáz-deficiens RCC. a) Jobbára eosinophil sejtes, papillaris morfológiájú daganat ismerhető fel, melyben solid és tubularis részletek (inzert) is jelen vannak (hematoxilin-eozin festés, 20x-os és 40x-es nagyítás). b) A fumarát-hidratáz fehérje nem fejeződik ki a tumorsejtekben, míg az ép vesetubulusok erős pozitív reakciót adnak (fumarát-hidratáz-immunhisztokémia, 10x-es nagyítás)

RCC $=$ vesesejtes carcinoma 


\section{Vesesejtes carcinoma prominens simaizomstromával (RCC with prominent smooth muscle stroma)}

Az első esetet 1993-ban írták le, majd 2005-ben közöltek egy 5 tumort vizsgáló részletes tanulmányt $[15,16]$. Azóta számos esetismertetés és vizsgálat látott napvilágot, de ismereteink erról a daganattípusról továbbra is limitáltak, sốt valószínúleg nem is egy konkrét entitásról, hanem hasonló morfológiát mutató daganatok összességéról van szó [7]. A daganatszövetet egy low-grade (ISUP grade 1 -es vagy 2 -es) világossejtes RCC-re emlékeztető epithelialis és egy prominens fibroleiomyomatosus stroma építi fel (3. ábra). Az utóbbi reaktívnak tekinthető, amit az is bizonyít, hogy polyclonalis sejtproliferációról van szó, mely valószínúleg az erek falának kötőszövetéből származik [17]. Jóllehet a pontos diagnosztikus kritériumok nem ismertek, ugyanis az eddig megjelent munkákban a morfológiai jegyek jelentős különbségeket mutattak. Az epithelialis komponens gyakran CK7-pozitív, ezért egyesek kapcsolatot feltételeztek ezen tumorféleség és a világossejtes papillaris RCC között [7]. Fontos hangsúlyozni, hogy az előbbiben gyakran csak gócos a CK7-pozitivitás, ezzel szemben CCPRCC-ben igen erôs intenzitású, diffúz CK7-festődés figyelhetô meg. Habár a megjelenés világossejtes RCC-re is emlékeztet, ezekben a tumorokban nem mutatható ki a $V H L$-génhez társuló genetikai eltérés [17].

\section{Fumarát-hidratáz-deficiens vesesejtes carcinoma (Fumarate hydratase-deficient RCC)}

A fumarát-hidratáz $(F H)$-deficiens RCC azon daganatok gyüjtőneve, melyek (1) megfelelő morfológiával rendelkeznek, (2) negatív bennük az FH-immunfestés és/vagy pozitívak S-(2-szukcinil)-cisztein (2SC)-ellenes antitesttel, (3) szindrómához társulás a klinikai adatok alapján bizonytalan, valamint (4) a szövettani vizsgálat időpontjában nem állnak rendelkezésre $F H$-gén-eltéréssel kapcsolatban genetikai adatok. Az $F H$-gén vesztése jellemzően csírasejtes eredetú, de egyesek feltételezik, hogy a betegség szomatikus mutáció miatt is kialakulhat, jóllehet erre nézve meggyőző adatok még nem állnak rendelkezésre. Az FH-gén csírasejtes mutációja miatt hereditaer leiomyomatosis és vesesejtes carcinoma (HLRCC) szindróma fejlődik ki, melyet fiatalkorban kialakuló nagyszámú cutan- és uterusleiomyoma megjelenése, továbbá vesesejtes carcinoma kifejlódése jellemez [6]. Meg kell jegyezni ugyanakkor, hogy ezek nem mindig jelennek meg együtt, és az esetek jelentős részében a vesesejtes carcinoma a HLRCC-szindróma első és egyetlen jele [18]. Az $F H$-gén által kódolt fumarát-hidratáz enzim a citromsavciklusban a fumarátot alakítja át maláttá. A fehérje hiánya esetén felszaporodik a fumarát, ami miatt a sejtek anyagcseréje az anaerob glikolízis felé tolódik el
(Warburg-effektus) ez aktiválja a hypoxia indukálta géneket, fokozza a sejtproliferációt, növeli az oxidatív streszszt, egyszóval kedvez a tumorok kialakulásának [19]. Az $F H$-deficiens RCC általában 45 év körül jelentkezik, férfiakban kétszer gyakoribb, és agresszív klinikai viselkedéssel társul [20]. A betegek több mint fele előrehaladott stádiumban kerül felismerésre, továbbá kb. 20\%-ban távoli áttétek is fennállnak. Morfológiailag tubularis, papillaris vagy tubulopapillaris mintázat észlelhetó, a daganatsejtek citoplazmája eosinophil, a sejtmagokban pedig, legalább fokálisan, nagy, CMV-inclusióra emlékeztető sejtmagvacska vehetô ki (4a ábra) [19]. Az FH-génben létrejövő mutáció általában a fehérje- és az enzimaktivitás teljes hiányához vezet, ezért az $F H$-deficiens tumorok negatív eredményt adnak FH-ellenes immunfestéssel ( $4 b$ ábra). Az enzimhiány miatt a citoplazmában felszaporodó szukcinát a fehérjék kémiai szerkezetét is módosítja (2SC-csoportok megjelenése), ami 2SC-ellenes antitesttel szintén detektálható. A két marker együttes használatával a daganat nagy biztonsággal diagnosztizálható, ugyanakkor meg kell jegyezni, hogy a 2SC-ellenes savó kereskedelmi forgalomban nem érhető el [20]. A tumor gyanúja, illetve FH-negativitás esetén genetikai vizsgálat javasolt, mely a gén célzott vizsgálata mellett magában kell, hogy foglalja az ősök és a leszármazottak szúrését is [21]. Ehhez klinikai genetikus bevonása is szükséges.

\section{Bifázisos squamoid papillaris vesesejtes carcinoma (Biphasic squamoid papillary RCC)}

Ez a daganattípus az l-es típusú papillaris RCC morfológiai spektrumán helyezkedik el [22]. Az irodalomban eddig kb. 100 esetet írtak le, melyek közül kettő beültetett vesében fejlődött ki [7]. A bifázisos squamoid papillaris RCC-re enyhe férfidominancia jellemző, életkori elófordulása tág határok között változik (39-79 év). Gyakori a többgócú és kétoldali megjelenés, továbbá gyakran társul más daganatokkal is, mint például papillaris adenoma, papillaris RCC, világossejtes RCC vagy urothelsejtes carcinoma [22]. Agresszív kórlefolyás és távoli áttétképződés az esetek 15\%-ában észlelhető [22]. Mikroszkóposan a tumorszövetet nagyobb és kisebb sejtek építik fel. A nagyobb sejtek laphámsejtekre emlékeztetnek, gyakran glomeruloid vagy micronodularis képződményeket hoznak létre. A kisebb sejtek pedig az l-es típusú papillaris RCC sejtjeire emlékeztetnek, ugyanis citoplazmájuk basophilen festődik, a sejtmagok pedig viszonylag kicsik ( $5 a$ ábra). Emperipolesis a nagy sejtek részéröl minden esetben megfigyelhetö, ezt a jelenséget a bifázisos squamoid papillaris RCC egyik pathognomicus eltérésének tartják [23]. Immunhisztokémiailag mindkét sejtpopuláció pozitív PAX8-, CK7-, AMACR-, CD10-, EMA- és vimentinellenes antitestekkel. A nagyobb sejtek csak morfológiailag emlékeztetnek a laphámsejtekre, de nem hordozzák azok immunfenotípusát (CK5/6- és 

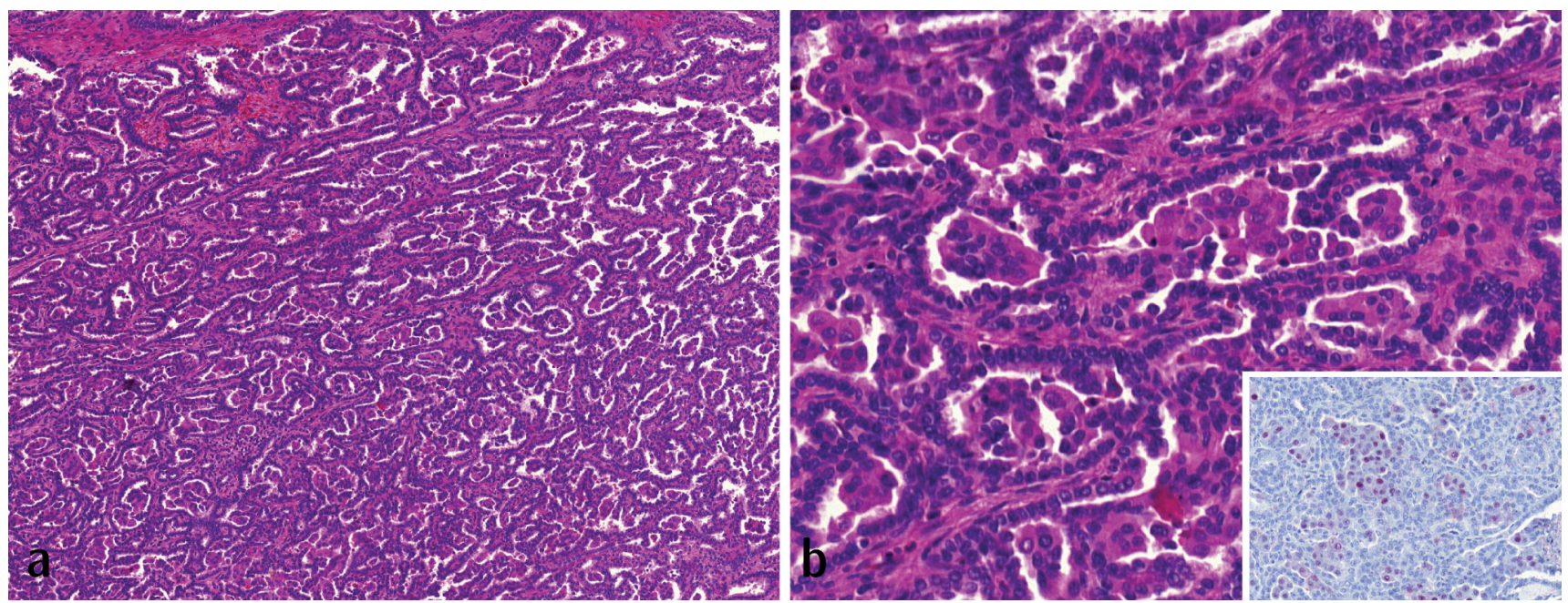

5. ábra

Bifázisos squamoid papillaris RCC. a) A növekedési mintázat papillaris, gócosan alveolusszerű képződmények is jelen vannak (hematoxilin-eozin festés, 10x-es nagyítás). b) Az utóbbiakban viszonylag nagy méretü, laphámsejtekre emlékeztető sejtek találhatók (hematoxilin-eozin festés, 40×-es nagyítás). Ezek a sejtek ciklin-Dl-pozitívak (inzert, ciklin-Dl-immunhisztokémia, 40×-es nagyítás)

RCC $=$ vesesejtes carcinoma

p63-negatívak), viszont általában erős ciklin-Dl-pozitivitást mutatnak (5b ábra) [22, 23]. Genetikailag a vizsgált esetek a 7-es és 17-es kromoszómák trisomiáját hordozták, továbbá férfiakban az Y-kromoszóma vesztése is jelen volt. Ezek mellett további polysomiák (12-es, 16-os és 20-as kromoszóma) és deletiók (21-es kromoszóma és Xp22.33-as régió) voltak azonosíthatók [7]. Differenciáldiagnosztikailag metanephricus adenoma (MA) és MTSC RCC merülhet fel. A MA elkülönítése nem okoz gondot, ugyanis ez a daganat CK7-negatív. A MTSC RCC differenciálása problémásabb, mert a két tumor immunfenotípusa teljesen egyezik, ezért ilyen esetekben molekuláris vizsgálatra kerülhet sor. A MTSC RCC-re nem jellemző a 7-es és 17-es kromoszómák trisomiája.

\section{Eosinophil solid és cysticus vesesejtes carcinoma (Eosinophilic solid and cystic RCC)}

Az eosinophil solid és cysticus RCC egy provizórikus RCC-altípus, melyből eddig kb. 60 esetet írtak le [7]. Az esetek 10\%-a sclerosis tuberosához társul [24]. Jóllehet a daganatok nagy része indolens lefolyású, négy esetben áttétképződés fordult elő, ami szükségessé teszi a betegek onkológiai utánkövetését [25]. A daganat jellemzően nőkben fordul eló, és a betegek medián életkora 55 év [25]. Szövetileg a tumorok alacsony nagyításon oncocytomára emlékeztetnek, de tüzetesebb áttekintés után fel-
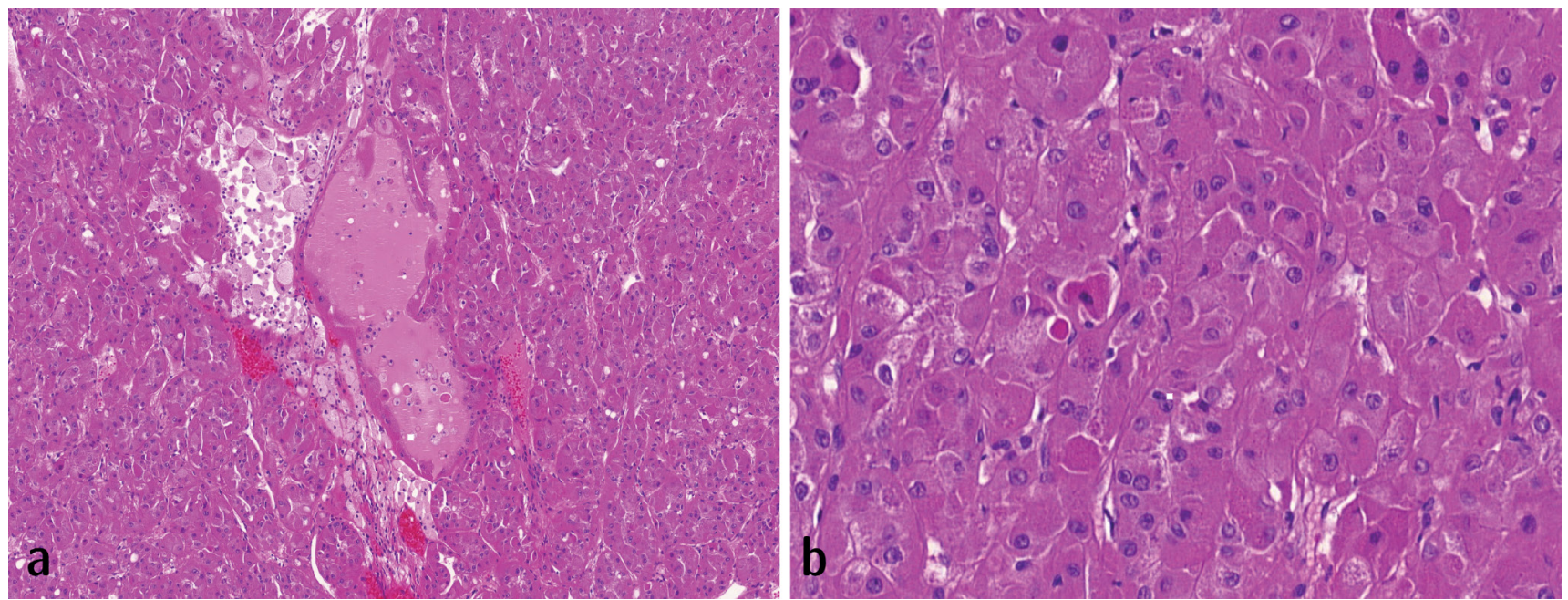

6. ábra

Eosinophil solid és cysticus RCC. a) A tumort bőséges eosinophil citoplazmájú sejtek építik fel, a növekedési mintázat solid, emellett fokálisan cysták is jelen vannak (hematoxilin-eozin festés, 10x-es nagyítás). b) A citoplazma helyenként szemcsézett, ami Leishmania-testekre emlékeztethet (hematoxilin-eozin festés, $40 x$-es nagyítás)

$\mathrm{RCC}=$ vesesejtes carcinoma 


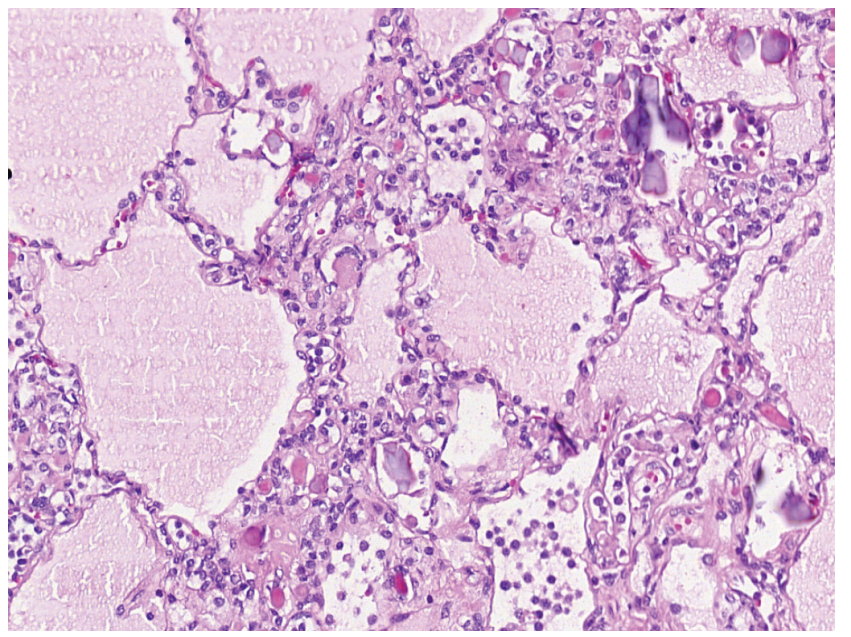

7. ábra

tat. Differenciáldiagnosztikailag szóba jön még az oncocytoma, de ez CD117-pozitív, míg az ESC RCC arra negatív. Genetikailag a daganatra az mTOR-ösvény génjeinek eltérései jellemzők [26].

\section{Atrophiás vesére emlékeztető vesesejtes carcinoma (Atrophic kidney-like RCC)}

Ebből a provizórikus tumortípusból mindössze öt esetet írtak le $[27,28]$. Ezek viszonylag fiatal életkorban fordultak elő (19-35 év). Eddig agresszív klinikai lefolyás sem ismert, ugyanakkor az esetek száma alacsony, és az utánkövetési idő is rövid [26, 27]. Makroszkóposan barna, szivacsszerú és jól körülírt tumorról van szó, a leírt daganatok mérete pedig 30 és 44 mm között volt [27, 28]. A daganat follicularis növekedési mintázatú; a folliculusokat lapos, sorvadt megjelenésű tumorsejtek építik fel, továbbá ezek centrumában besűrûsödött eosinophil szekrétum látható, így az összkép a végstádiumú vesékben látott pajzsmirigyszerü átalakulásra emlékeztet [27, 28]. A daganatban gyakran látni dystrophiás vagy psammomatosus meszesedést is (7. ábra). A daganatsejtek változó mértékben pozitívak PAX8-cal és CK7-tel. Differenciáldiagnosztikai szempontból szóba jön a pajzsmirigyszerú folliculus RCC, de elkülönítésüket a különböző morfológiai jegyek segítik [27, 28].

moron belül, melyeket jancsiszeg (hobnail) megjelenésú, bőséges eosinophil citoplazmájú daganatsejtek bélelnek. A szolid területeken változó mértékben gyulladásos sejtek is kimutathatók. A citoplazmában időnként eosinophil rögök és lila globulusok is jelen vannak, az utóbbiak a Leishmania-testekre emlékeztetnek (6. ábra) [26]. Az ESC RCC az egyetlen olyan veserákaltípus, amely CK20-pozitív, ezzel szemben a CK7-festés általában negatív vagy legfeljebb gócosan pozitív [25]. Ez segíti a tumor elkülönítését a chromophob RCC-től, mely CK7-tel az esetek többségében kiterjedt pozitivitást mu-

\section{Világossejtes vesesejtes carcinoma óriássejtekkel és emperipolesissel (Clear cell RCC with giant cells and emperipolesis)}

Az emperipolesis számos daganattípusban ismert jelenség, világossejtes veserákokban azonban ritkán fordul elő. Korábban csak egy-egy esetismertetést közöltek, de
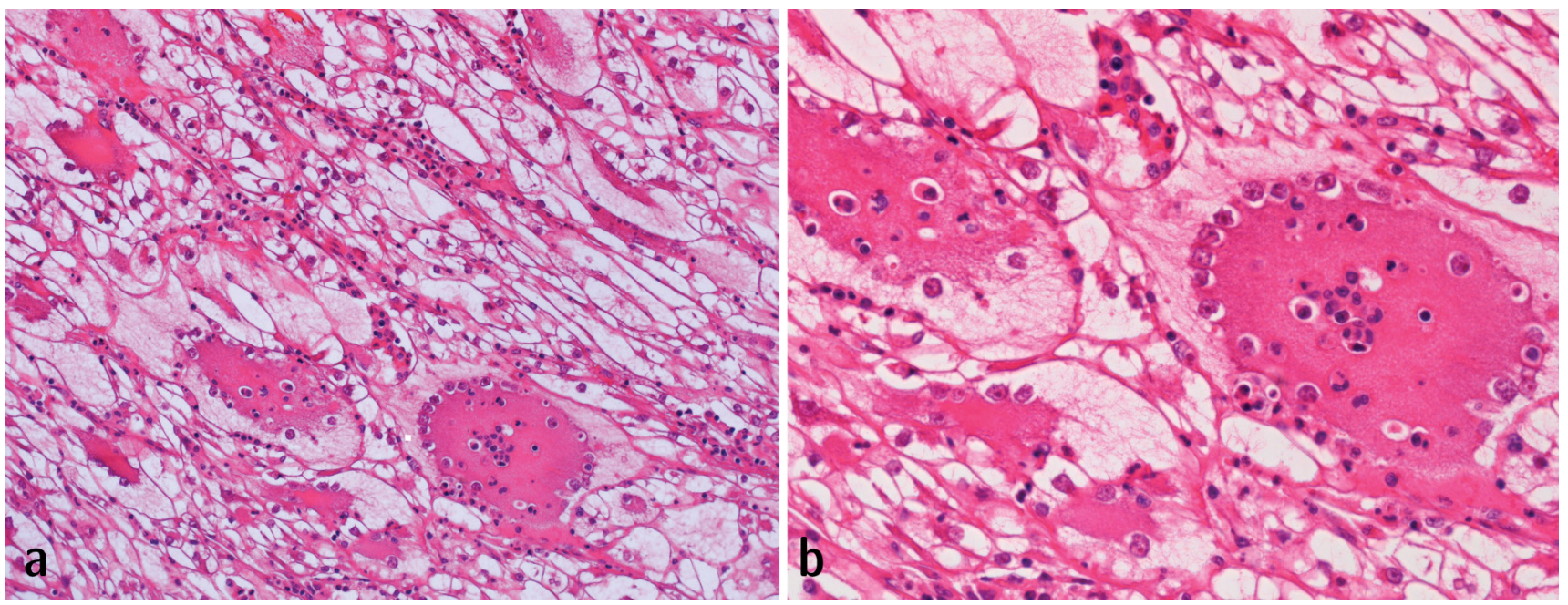

8. ábra

Világossejtes RCC óriássejtekkel és emperipolesissel. a) A világos citoplazmájú tumorsejtek között nagyszámú, többmagvú óriássejt is kivehető (he matoxilin-eozin festés, 20×-os nagyítás). b) Az óriássejtek citoplazmájában bekebelezett gyulladásos sejtek észlelhetők (hematoxilin-eozin festés, $40 \times$-es nagyítás)

$\mathrm{RCC}=$ vesesejtes carcinom 
nem olyan rég összesen 27 eset került részletes leírásra, ennek ellenére a dokumentált esetek száma alacsony [29-31]. Erre a veserákaltípusra az agresszív és kedvezőtlen klinikai kórlefolyás jellemző [30]. Makroszkóposan a daganat megkülönböztethetetlen a „klasszikus” világossejtes RCC-től, a metszéslap kénsárga, melyen változó mértékben szürkésfehér területek is jelen vannak. Mikroszkóposan a tumorszövetet jellemzően nagy, szemcsézett citoplazmájú sejtek építik fel, melyek egy vagy több sejtmaggal bírnak $[30,31]$. Gyakori a rhabdoid átalakulás, továbbá az óriássejtek syncytiotrophoblastokra is emlékeztethetnek. Az ilyen területek mellett vagy azokkal keveredve „klasszikus” világossejtes RCC is felismerhető. Emperipolesis csak az óriássejtek részéről volt megfigyelhető, a low-grade területeken ez nincs jelen (8. ábra). Az immunprofil és a genetikai eltérések összhangban állnak a világossejtes RCC-ben látottakkal, nevezetesen a tumorsejtek diffúz pozitivitást mutatnak a szénsavanhidráz-9-ellenes savóval, továbbá VHL-gén-eltérések (deletio, mutáció vagy promoterrégió-hipermetiláció) észlelhetők [30, 31]. Meg kell jegyezni azonban, hogy egyesek szerint az emperipolesis önmagában nem befolyásolja a prognózist, és azt csupán morfológiai eltérésként tartják számon [7, 22, 23].

\section{Warthin-szerú papillaris carcinoma (Warthin-like papillary RCC)}

A daganat kétszer gyakoribb férfiakban, mint nőkben, továbbá életkori előfordulása is széles (14-76 év) [32]. Áttétes betegség az esetek nagyjából egyharmadában alakul ki [7]. A növekedési mintázat papillaris, a papillák felszínén oncocytás karakterü sejtek láthatók, melyek jel-

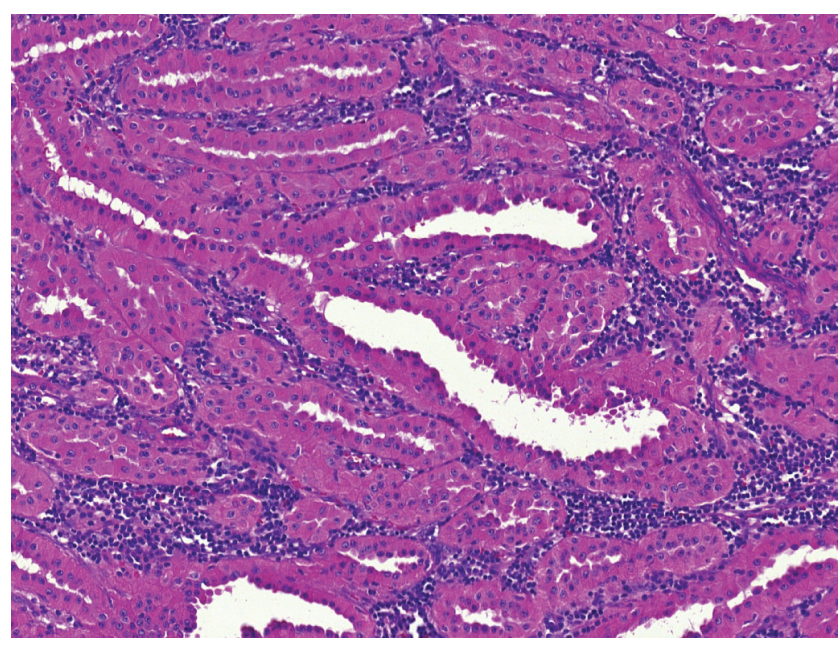

9. ábra

Warthin-szerú papillaris RCC. A daganatot oncocytás karakterú sejtek építik fel. A növekedési mintázat papillaris. A papillák tengelyében, valamint a stromában lymphoplasmocytás infiltrátum található (hematoxilin-eozin festés, 20x-os nagyítás)

RCC $=$ vesesejtes carcinoma lemzően ISUP grade 3-as differenciáltságúak. A papillák tengelyében és a stromában - a nyálmirigyekben észlelhető Warthin-tumorhoz hasonlóan - lymphocytákban gazdag infiltrátum található (9. ábra). A daganatban pozitív a PAX8, az AMACR, a vimentin, a CK7 és az antimitokondriális immunfestés, továbbá negatív a CA9, a CD117, a CK20 és a TTF1 [32]. Genetikailag, a vizsgált esetekben eusomia volt kimutatható, kivéve egy esetet, amelyben a 7-es és a 17-es kromoszóma trisomiája látszódott [32, 33]. Mivel a Warthin-szerű papillaris carcinoma csak provizórikus entitás, az ilyen daganatokat egyelőre 2-es típusú papillaris RCC-nek javasolt tekinteni [7].

\section{Low-grade oncocytás vesetumor (CD117-negatív, CK7-pozitív) (Low-grade oncocytic renal tumor [CD117-negative, CK7-positive])}

Az oncocytoma és a chromophob RCC differenciálása időnként komoly nehézségekbe ütközik, viszont a két tumortípus elkülönítése elengedhetetlen, hiszen az előbbi jóindulatú, az utóbbi viszont rosszindulatú, ami a beteg onkológiai utánkövetését indokolja [6]. Mindkét tumortípus CD117-pozitív, viszont CK7-expressziójuk eltér. A chromophob RCC kiterjedt (gyakran diffúz) CK7-pozitivitást mutat, ezzel szemben oncocytomában a CK7 gócosan, jellemzően egy-egy sejtben pozitív csupán [6]. Az utóbbi időben 29 olyan daganat került leírásra, melyek fénymikroszkóposan mind az oncocytoma, mind a chromophob RCC jellemvonásait hordozták, és érdekes módon ezek CK7-pozitívnak, de CD117-negatívnak bizonyultak [34-36]. A betegek típusosan 60 év feletti nők (a medián életkor 67 év) [36]. Makroszkóposan a daganat mahagónibarna, továbbá átlagosan 30 mm legnagyobb átmérőjü. Szövetileg a tumorsejtek oncocytás vagy eosinophil citoplazmával rendelkeznek, a sejtmagok kicsik (ISUP grade 2-es), melyek körül gócosan „halo" képződése is kimutatható (10a ábra). A növekedési mintázat változatos, lehet solid, tubularis vagy trabecularis [36]. Ahogy a tumortípus neve is jelzi, a daganat CD117-negatív és CK7-pozitív, (10b ábra) további pozitív markerek még a PAX8, E-kadherin és BerEP4, valamint negatív a CA9-, CK20-, CK5/6-, p63-, CD15-, HMB45-, MelanA- és vimentinfestés. A CD10-, illetve AMACR-reakciók lehetnek gócosan pozitívak vagy negatívak [36]. A tumorra a 19p33.3-as és lp36.33-as kromoszómarégiók deletiója jellemző. Túlélési adat csupán 16 beteg kapcsán állt rendelkezésre, viszont ezekben a betegekben sem lokális recidíva, sem pedig távoli áttét nem alakult ki (a medián utánkövetési idő 23,5 hónap volt) [36]. A jelenleg érvényes WHO-beosztás szerint ez a tumor a hibrid oncocytás/chromophob tumor kategóriába sorolandó, mely a chromophob RCC altípusának felel meg [6]. 

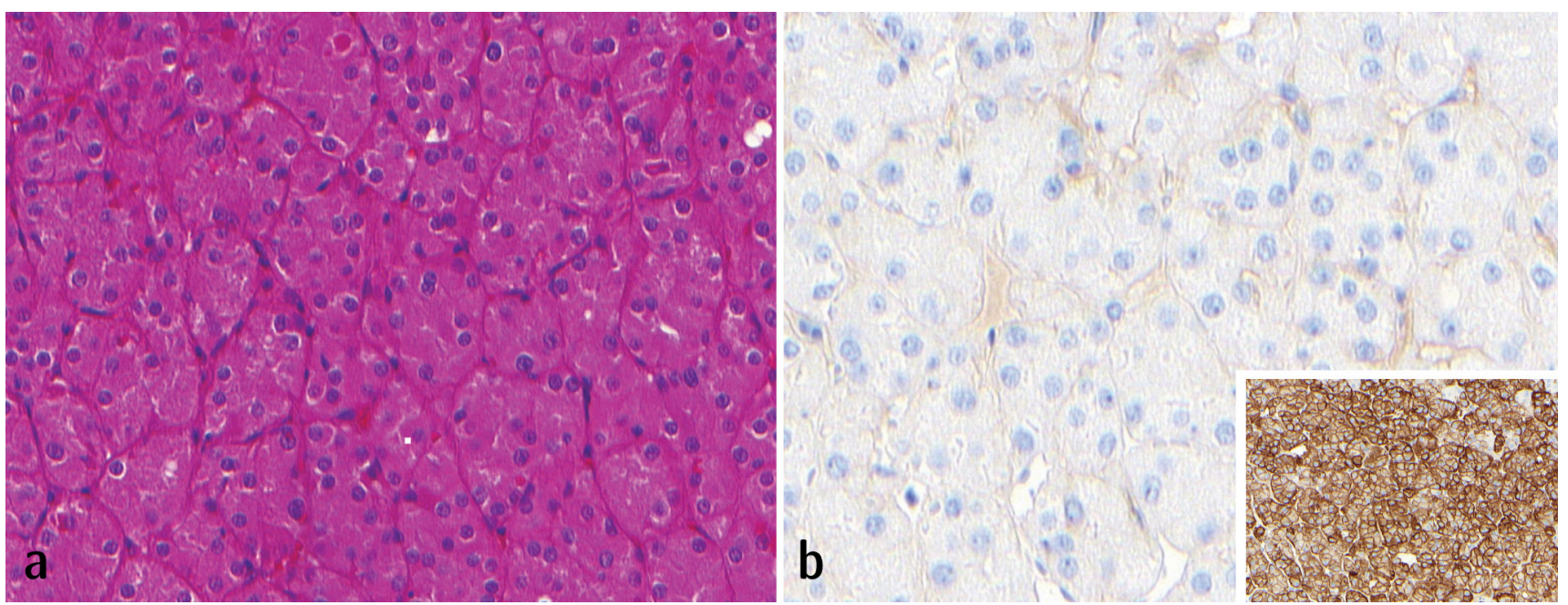

10. ábra

Low-grade oncocytás vesetumor (CD117-negatív, CK7-pozitív). a) A daganatot eosinophilan szemcsézett citoplazmájú tumorsejtek építik fel. A növekedési mintázat solid, a fészkek között fibrovascularis septumok vehetők ki (hematoxilin-eozin festés, 40×-es nagyítás). b) Immunhisztokémiailag a daganatsejtek CD117-negatívak, de a CK7-festés (inzert) diffúzan pozitív (CD117- és CK7-immunhisztokémia, 40×-es nagyítás)

CD117 = differenciációs klaszter-117; CK7 = citokeratin-7

\section{High-grade oncocytás vesetumor (High-grade oncocytic renal tumor)}

Ezt a tumortípust 2018-ban írták le elöször. He és mtsai 14 olyan daganatot azonosítottak, melyek azon túl, hogy hordozták az oncocytoma, illetve a chromophob carcinoma jellemvonásait, további sajátos morfológiai jegyekkel is rendelkeztek [37]. A daganattípus nókben háromszor olyan gyakori, mint férfiakban, és a betegek az átlag veserákos populációhoz képest némileg fiatalabbak (a medián életkor 50 év). Makroszkóposan a tumor tokkal nem rendelkezik, és homogén barna színü. A vizsgált daganatok mindegyike pTl-es stádiumú volt [37]. A növekedési mintázat solid, esetleg tubulocysticus, a tumor- sejtek pedig oncocytás karakterúek, de perinuclearis "halo" képződése nincs bennük. A magatípia kifejezett (ISUP grade 3-as), továbbá gyakran észlelni intracitoplazmatikus vakuólumokat is (11.ábra). A daganatsejtek között időnként csapdába esett nephronszegmensek, illetve vaskos falú érátmetszetek is jelen vannak. A neoplasticus sejtek jellemzően pozitívak CK7, CD117, MIA, PAX8, SDHB, CD10 és katepszin K immunmarkerekkel, ugyanakkor negatív a MelanA- és a HMB45-festés. Genetikailag TFE3- vagy TFEB-transzlokáció nem észlelhető, továbbá egész kromoszómákat érintő deletiók sincsenek jelen, de számos különböző és nem konzisztens kromoszómaszegmenst érintő vesztésekről és duplikációkról számoltak be [37]. A legújabb eredmények
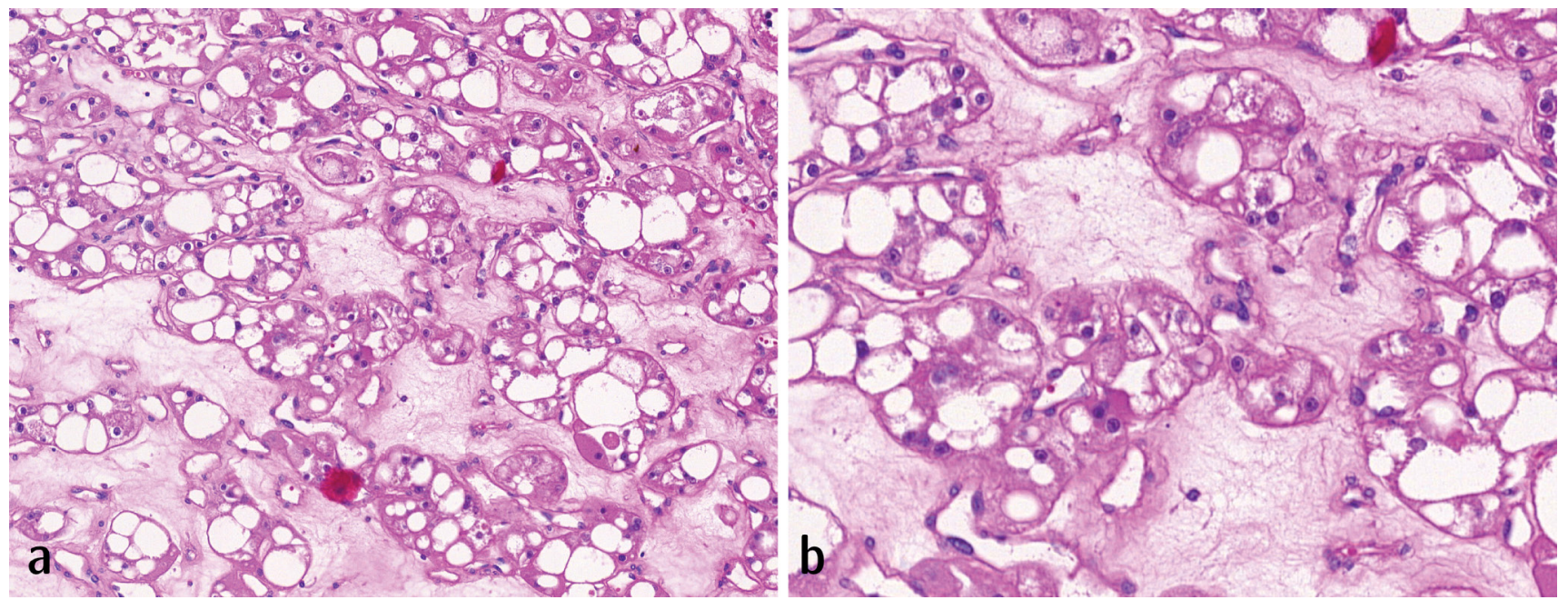

11. ábra festés, 20x-os nagyitás). b) A magatípia kifejezett, általában ISUP grade 3-as (hematoxilin-eozin festés, 40x-es nagyítás)
(a)

ISUP = Nemzetközi Uropatológiai Társaság 

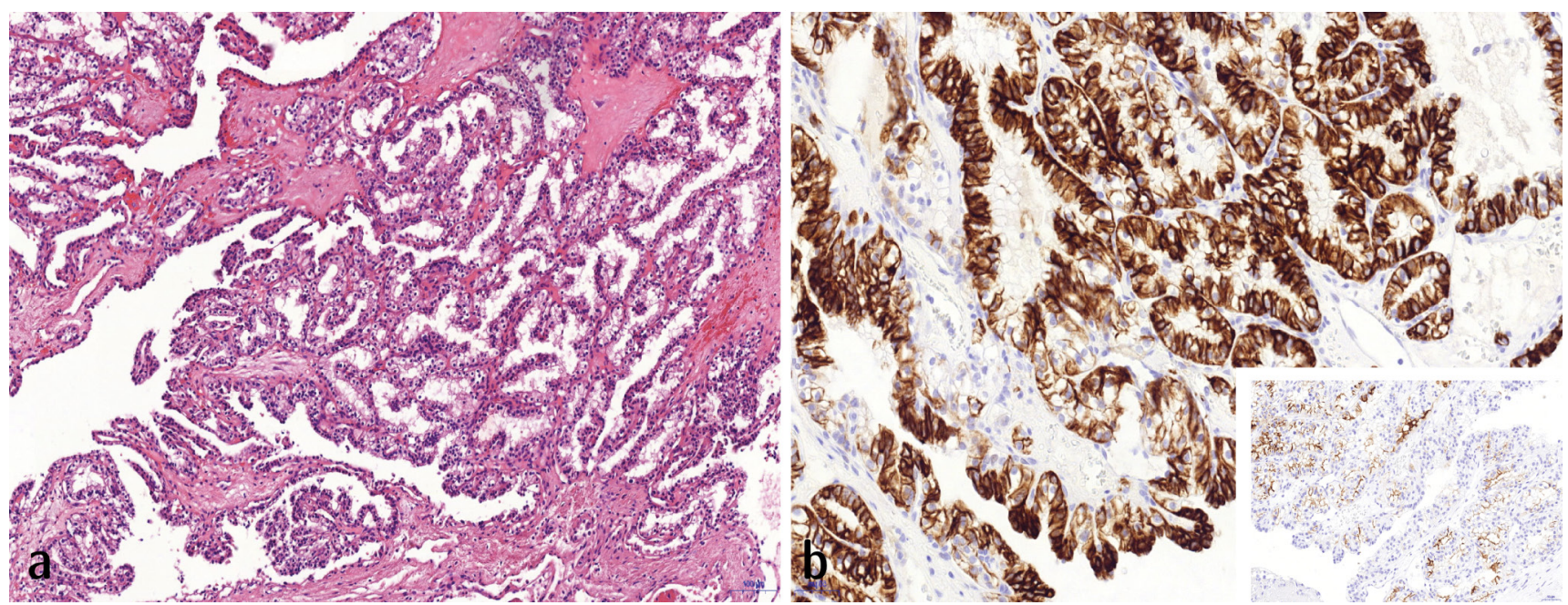

12. ábra

TCEB1-mutáns RCC. A) A daganatot világos citoplazmájú tumorsejtek építik fel, a magatípia alacsony (ISUP grade 1-2-es). A növekedési mintázat tubulopapillaris, a stroma pedig simaizomban gazdag (hematoxilin-eozin festés, 40×-es nagyítás). B) Differenciáldiagnosztikailag világossejtes papillaris RCC jön szóba. A CK7-immunfestés intenzitása és kiterjedése alacsonyabb, mint világossejtes papillaris RCC-ben (CK7-immunhisztokémia, 20×-os nagyítás). A CDl0-festés gyakran diffúz pozitív reakciót ad, ami a világossejtes papillaris RCC ellen szól (inzert, CDl0-immunhisztokémia, $10 \times$-es nagyítás)

CD10 = differenciációs klaszter-10; CK7 = citokeratin-7; ISUP = Nemzetközi Uropatológiai Társaság; RCC = vesesejtes carcinoma; TCEB1 = elongációs megnyúlási faktor $\mathrm{Bl}$

szerint a tumorsejtekben az mTOR-ösvényhez kapcsolható gének eltérései mutathatók ki, sőt egy esetismertetés szerint a tumor sclerosis tuberosához is társulhat [7, 38]. A betegség a kevés elérhető utánkövetési adat alapján indolens lefolyású [37].

\section{TCEBI-mutáns carcinoma (TCEBI-mutated RCC)}

A világossejtes RCC-re a $V H L$-gén inaktivációja, illetve a 3-as kromoszóma rövid karjához kapcsolható genomi eltérések jellemzők [6]. Nagy áteresztőképességü genetikai vizsgálatok azonban kimutatták, hogy az esetek durván $10 \%$-ában a fentebb részletezett eltérések nincsenek jelen [39]. Ezt a csoportot tovább vizsgálva észlelték, hogy egyes daganatokban a TCEBl-gén mutációi és/ vagy a teljes 8 -as kromoszóma vagy pedig a 8 -as kromoszóma hosszú karjának (8q) vesztése áll fenn [40]. A TCEBI az elongin C-fehérjét kódolja, mely a VHL-fehérjét kapcsolja össze az E3-ubikvitinázzal, ezáltal részt vesz a HIFl $\alpha$ inaktiválásában [6]. A leírt mutációk kizárólag a fehérje HIF-kötő helyét érintették [40]. Mikroszkóposan a daganat világos citoplazmájú sejtekből épül fel, a növekedési mintázat pedig tubularis, papillaris, solid, illetve ezek keveredéséből tevődik össze (12a ábra). A stroma és a daganat áltokja simaizomban gazdag, ezért differenciáldiagnosztikailag világossejtes papillaris RCC merül fel [40]. Elkülönítésüket segíti a CA9-et, CDl0et és CK7-et tartalmazó immunhisztokémiai panel. A világossejtes papillaris RCC CA9-et és CK7-et koexpresszál; az előbbi gyakran csak basolateralis (ún. „cupshaped”) pozitivitást mutat, a CDl0-festés pedig negatív vagy igen fokálisan pozitív (12b ábra). Ezekkel szemben a TCEBl-mutáns RCC diffúzan pozitív CD10-zel és CA9-cel; az utóbbi esetén a sejtek valamennyi felszíne festődik, a CK7-reakció pedig fokális, ún. foltos pozitivitást jelez $[6,40]$. Az ilyen típusú daganatok jellemzően jól differenciáltak és szervre lokalizáltak. Az eddig közölt esetekben a betegség indolens lefolyású volt, és daganat miatti halálozás nem fordult elő [40].

\section{Chromophob carcinoma neuroendokrin vonásokkal (Chromophobe RCC with neuroendocrine features)}

Ritkán chromophob RCC-ben neuroendokrin jellemzők ismerhetők fel [41], melyek a következők: kicsi, só-bors kromatinállománnyal rendelkező sejtmagok jelenléte, jellegzetes szigetszerű vagy cribriform (pseudorosettoid) növekedési mintázat, neuroendokrin markerek (kromogranin A, szinaptofizin, CD56 stb.) kifejeződése, valamint neuroszekréciós granulumok megléte [42]. A két komponens nem válik el élesen egymástól, hanem a „klasszikus” ChRCC keveredik a neuroendokrin karakterü sejtekkel [42]. Ezekre a daganatokra jellemző az 1-es, 2-es, 6-os, 10-es és 17-es kromoszómák elvesztése is [42]. A klinikai viselkedés a „klasszikus” ChRCC-vel szemben agresszív, és a betegség gyakran halálos kimenetelü [42].

\section{Megbeszélés}

A szokatlan morfológiával bíró daganatok részletes, tudományos feldolgozása kétféle eredménnyel zárulhat. Egyrészt lehetséges, hogy a látott atípusos megjelenés 
csupán egy, már ismert szövettani altípus szokatlan morfológiai variánsa. Ilyen lehet az itt tárgyaltak közül a Warthin-szerü papillaris carcinoma vagy a bifázisos squamoid papillaris carcinoma, melyek összeségében a „klaszszikus" papillaris RCC-re jellemző genetikai eltéréseket hordozzák, és kórlefolyásuk sem különbözik jelentősen. Másrészt az ilyen típusú vizsgálatok elvezethetnek új altípusok leírásához is. A fentebb leírt daganatok közül igen nagy valószínúséggel ilyen a TCEBl-mutáns RCC, valamint az ESC RCC és a high-grade oncocytás vesetumor, melyeknek sajátságos immunfenotípusuk és genetikai hátterük van. Új entitás, illetve morfológiai variáns elkülönítése csak nagyszámú eset konzekvens vizsgálata és konszenzuskonferencián történő megbeszélés után lehetséges. A hazai tapasztalat az itt részletezett RCC altípusokkal/morfológiai variánssokkal kapcsolatban limitált. A szerzők diagnosztikus munkájuk során három alkalommal találkoztak $F H$-deficiens RCC-vel, egyszer pedig TCEB1-mutáns RCC-vel. Saját gyakorlatukban az emperipolesist is tartalmazó világossejtes RCC-t nem különítik el a „konvencionális” világossejtes veseráktól, a jelenséget csupán egy ritka morfológiai eltérésként tartják számon. A hagyományos RCC-altípusok elkülönítése nem igényel speciális uropatológiai jártasságot, de atípusos morfológia vagy szokatlan kórlefolyás kapcsán szükséges, hogy az esetet vesetumorokban jártas patológus is áttekintse: ez fokozhatná a diagnosztikus pontosságot és a tapasztalatok megosztását, illetve lehetôvé tenné a betegek uroonkológiai centrumokba történő irányítását, valamint a ritka esetek szervezett gyưjtését és utánkövetését is. Hangsúlyozni kell, hogy FH-deficiens RCC-re emlékeztető morfológia esetén nemcsak patológiai, hanem klinikai genetikai konzílium is szükséges, az esetek ugyanis döntően HLRCC-szindrómához társulnak, habár feltételezik, hogy szomatikus genetikai/epigenetikai eltérés révén is kialakulhatnak [43].

Anyagi támogatás: A közlemény megírása anyagi támogatásban nem részesült.

Szerzői munkamegosztás: J. A.: Az irodalmi adatok áttekintése, rendszerezése, a szöveg szerkesztése. K. L.: Az irodalmi adatok áttekintése, rendszerezése, a szöveg és az ábrák szerkesztése. A cikk végleges változatát mindkét szerző elolvasta és jóváhagyta.

Érdekeltségek: A szerzőknek nincsenek érdekeltségeik.

\section{Irodalom}

[1] Kovacs G, Akhtar M, Beckwith JB, et al. The Heidelberg classification of renal cell tumours. J Pathol. 1997; 183: 131-133.

[2] Eble JN, Sauter G, Epstein JI, et al. (eds.) Pathology and genetics of tumors of the urinary system and male genital organs. International Agency for Research on Cancer, Lyon, 2004.

[3] Srigley JR, Delahunt B, Eble JN, et al. The International Society of Urological Pathology (ISUP) Vancouver classification of renal neoplasia. Am J Surg Pathol. 2013; 37: 1469-1489.
[4] Delahunt B, Cheville JC, Martignoni G, et al. The International Society of Urological Pathology (ISUP) grading system for renal cell carcinoma and other prognostic parameters. Am J Surg Pathol. 2013; 37: 1490-1504.

[5] Trpkov K, Grignon DJ, Bonsib SM, et al. Handling and staging of renal cell carcinoma: the International Society of Urological Pathology Consensus (ISUP) conference recommendations. Am J Surg Pathol. 2013; 37: 1505-1517.

[6] Moch H, Humphrey PA, Ulbright TM, et al. (eds.) WHO classification of tumours of the urinary system and male genital organs. International Agency for Research on Cancer, Lyon, 2016.

[7] Trpkov K, Hes O. New and emerging renal entities: a perspective post - WHO 2016 classification. Histopathology 2019; 74: 3159.

[8] Amin MB, Radhakrishnan A, Hes O, et al. Primary thyroid-like follicular carcinoma of the kidney: a histologically distinctive primary renal epithelial tumor. Mod Pathol. 2004; 17(Suppl 1): 136A.

[9] Amin MB, Gupta R, Hes O, et al. Primary thyroid-like follicular carcinoma of the kidney: report of 6 cases of a histologically distinctive adult renal epithelial neoplasm. Am J Surg Pathol. 2009; 33: 393-400.

[10] Dhillon J, Tannir NM, Matin SF, et al. Thyroid-like follicular carcinoma of the kidney with metastases to the lungs and retroperitoneal lymph nodes. Hum Pathol. 2011; 42: 146-150.

[11] Mano H. ALKoma: a cancer subtype with a shared target. Cancer Discov. 2012; 2: 495-502.

[12] Cajaiba MM, Dyer LM, Geller JI, et al. The classification of pediatric and young adult renal cell carcinomas registered on the Children's Oncology Group (COG) protocol AREN03B2 after focused genetic testing. Cancer 2018; 124: 3381-3389.

[13] Cajaiba MM, Jennings LJ, Rohan SM, et al. ALK-rearranged renal cell carcinomas in children. Genes Chromosomes Cancer 2016; 55: 442-451.

[14] Sugawara E, Togashi Y, Kuroda N, et al. Identification of anaplastic lymphoma kinase fusions in renal cancer: large-scale immunohistochemical screening by the intercalated antibodyenhanced polymer method. Cancer 2012; 118: 4427-4436.

[15] Canzonieri V, Volpe R, Gloghini A, et al. Mixed renal tumor with carcinomatous and fibroleiomyomatous components, associated with angiomyolipoma in the same kidney. Pathol Res Pract. 1993; 189: 951-956.

[16] Kuhn E, De Anda J, Manoni S, et al. Renal cell carcinoma associated with prominent angioleiomyoma-like proliferation: report of 5 cases and review of the literature. Am J Surg Pathol. 2006; 30: 1372-1381.

[17] Shannon BA, Cohen RJ, Segal A, et al. Clear cell renal cell carcinoma with smooth muscle stroma. Hum Pathol. 2009; 40: 425429.

[18] Smith SC, Trpkov K, Chen YB, et al. Tubulocystic carcinoma of the kidney with poorly differentiated foci: a frequent morphologic pattern of fumarate hydratase-deficient renal cell carcinoma. Am J Surg Pathol. 2016; 40: 1457-1472.

[19] Warburg O. On the origin of cancer cells. Science 1956; 123 : 309-314.

[20] Trpkov K, Hes O, Agaimy A, et al. Fumarate hydratase-deficient renal cell carcinoma is strongly correlated with fumarate hydratase mutation and hereditary leiomyomatosis and renal cell carcinoma syndrome. Am J Surg Pathol. 2016; 40: 865-875.

[21] Menko FH, Maher ER, Schmidt LS, et al. Hereditary leiomyomatosis and renal cell cancer (HLRCC): renal cancer risk, surveillance and treatment. Fam Cancer 2014; 13: 637-644.

[22] Hes O, Condom Mundo E, Peckova K, et al. Biphasic squamoid alveolar renal cell carcinoma: a distinctive subtype of papillary renal cell carcinoma? Am J Surg Pathol. 2016; 40: 664-675.

[23] Trpkov K, Athanazio D, Magi-Galluzzi C, et al. Biphasic papillary renal cell carcinoma is a rare morphological variant with fre- 
quent multifocality: a study of 28 cases. Histopathology 2018; 72: 777-785.

[24] Trpkov K, Hes O, Bonert M, et al. Eosinophilic, solid, and cystic renal cell carcinoma: clinicopathologic study of 16 unique, sporadic neoplasms occurring in women. Am J Surg Pathol. 2016; 40: 60-71.

[25] Tretiakova MS. Eosinophilic solid and cystic renal cell carcinoma mimicking epithelioid angiomyolipoma: series of 4 primary tumors and 2 metastases. Hum Pathol. 2018; 80: 65-75.

[26] Trpkov K, Abou-Ouf H, Hes O, et al. Eosinophilic solid and cystic renal cell carcinoma (ESC RCC): further morphologic and molecular characterization of ESC RCC as a distinct entity. Am J Surg Pathol. 2017; 41: 1299-1308.

[27] Hes O, de Souza TG, Pivovarcikova K, et al. Distinctive renal cell tumor simulating atrophic kidney with 2 types of microcalcifications. Report of 3 cases. Ann Diagn Pathol. 2014; 18: 82-88.

[28] Oshiro Y, Hida AI, Tamiya S, et al. Bilateral atrophic kidney-like tumors. Pathol Int. 2014; 64: 478-480.

[29] Shen R, Wen P. Clear cell renal cell carcinoma with syncytial giant cells: a case report and review of the literature. Arch Pathol Lab Med. 2004; 128: 1435-1438.

[30] Williamson SR, Kum JB, Goheen MP, et al. Clear cell renal cell carcinoma with a syncytial-type multinucleated giant tumor cell component: implications for differential diagnosis. Hum Pathol. 2014; 45: 735-744.

[31] Rotterova P, Martinek P, Alaghehbandan R, et al. High-grade renal cell carcinoma with emperipolesis: clinicopathological, immunohistochemical and molecular-genetic analysis of 14 cases. Histol Histopathol. 2018; 33: 277-287.

[32] Skenderi F, Ulamec M, Vanecek T, et al. Warthin-like papillary renal cell carcinoma: clinicopathologic, morphologic, immunohistochemical and molecular genetic analysis of 11 cases. Ann Diagn Pathol. 2017; 27: 48-56.

[33] Pitra T, Pivovarcikova K, Alaghehbandan R, et al. Chromosomal numerical aberration pattern in papillary renal cell carcinoma. Ann Diagn Pathol. 2019; 40: 189-199.

[34] Davis CF, Ricketts CJ, Wang M, et al. The somatic genomic landscape of chromophobe renal cell carcinoma. Cancer Cell 2014; 26: 319-330.
[35] Kuroda N, Tanaka A, Yamaguchi T, et al. Chromophobe renal cell carcinoma, oncocytic variant: a proposal of a new variant giving a critical diagnostic pitfall in diagnosing renal oncocytic tumors. Med Mol Morphol. 2013; 46: 49-55.

[36] Trpkov K, Williamson SR, Martinek P, et al. Oncocytic renal tumors with CD1 17 negative, cytokeratin 7 positive immunoprofile are different from eosinophilic chromophobe renal cell carcinoma and oncocytoma. Mod Pathol. 2018; 31(Suppl S2): 393A.

[37] He H, Trpkov K, Martinek P, et al. "High-grade oncocytic renal tumor": morphologic, immunohistochemical, and molecular genetic study of 14 cases. Virchows Arch. 2018; 473: 725-738.

[38] Trpkov K, Bonert M, Gao Y, et al. High-grade oncocytic tumour (HOT) of kidney in a patient with tuberous sclerosis complex. Histopathology 2019; 75: 440-442.

[39] Turajlic S, Xu H, Litchfield K, et al. Deterministic evolutionary trajectories influence primary tumor growth: TRACERx Renal. Cell 2018; 173: 595-610.el1.

[40] Hakimi AA, Tickoo SK, Jacobsen A, et al. TCEB1-mutated renal cell carcinoma: a distinct genomic and morphological subtype. Mod Pathol. 2015; 28: 845-853.

[41] Ohe C, Kuroda N, Matsuura K, et al. Chromophobe renal cell carcinoma with neuroendocrine differentiation/morphology: a clinicopathological and genetic study of three cases. Hum Pathol Case Rep. 2014; 1: 31-39.

[42] Peckova K, Martinek P, Ohe C, et al. Chromophobe renal cell carcinoma with neuroendocrine and neuroendocrine-like features. Morphologic, immunohistochemical, ultrastructural, and array comparative genomic hybridization analysis of 18 cases and review of the literature. Ann Diagn Pathol. 2015; 19: 261-268.

[43] Harrison WJ, Andrici J, Maclean F, et al. Fumarate hydratasedeficient uterine leiomyomas occur in both the syndromic and sporadic settings. Am J Surg Pathol. 2016; 40: 599-607.

(Kuthi Levente dr., Szeged, Állomás u 1., 6725 e-mail: kuthi.levente@med.u-szeged.hu)

\section{A rendezvények és kongresszusok híranyagának leadása}

a lap megjelenése előtt legalább 40 nappal lehetséges, a 6 hetes nyomdai átfutás miatt. Kérjük megrendelőink szíves megértését.

A híranyagokat a következő címre kérjük:

Orvosi Hetilap titkársága: edit.budai@akademiai.hu

Akadémiai Kiadó Zrt.

A cikk a Creative Commons Attribution 4.0 International License (https://creativecommons.org/licenses/by/4.0/) feltételei szerint publikált Open Access közlemény, melynek szellemében a cikk bármilyen médiumban szabadon felhasználható, megosztható és újraközölhető, feltéve, hogy az eredeti szerző és a közlés helye, illetve a CC License linkje és az esetlegesen végrehajtott módosítások feltüntetésre kerülnek. (SID_1) 